STUDI

FRANCESI

\section{Studi Francesi}

Rivista quadrimestrale fondata da Franco Simone

145 (XLIX | I) | 2005

Varia - fasc. I - gennaio-aprile 2005

\title{
Aimé Césaire, Le discours sur la Négritude, Miami 1987 / Discourse on Negritude, Miami 1987
}

\section{Paola Ghinelli}

\section{(2) OpenEdition}

1 Journals

\section{Édition électronique}

URL : http://journals.openedition.org/studifrancesi/36833

DOI : $10.4000 /$ studifrancesi.36833

ISSN : 2427-5856

Éditeur

Rosenberg \& Sellier

\section{Édition imprimée}

Date de publication : 1 juillet 2005

Pagination : 210-211

ISSN : 0039-2944

\section{Référence électronique}

Paola Ghinelli, « Aimé Césaire, Le discours sur la Négritude, Miami 1987 / Discourse on Negritude, Miami 1987 », Studi Francesi [En ligne], 145 (XLIX | I) | 2005, mis en ligne le 30 novembre 2015, consulté le 18 avril 2021. URL : http://journals.openedition.org/studifrancesi/36833 ; DOI : https://doi.org/10.4000/ studifrancesi.36833

Ce document a été généré automatiquement le 18 avril 2021.

\section{(c) $(1) \ominus$}

Studi Francesi è distribuita con Licenza Creative Commons Attribuzione - Non commerciale - Non opere derivate 4.0 Internazionale. 


\section{Aimé Césaire, Le discours sur la Négritude, Miami 1987 / Discourse on Negritude, Miami 1987}

Paola Ghinelli 


\section{RÉFÉRENCE}

AIMÉ CÉSAIRE, Le discours sur la Négritude, Miami 1987 / Discourse on Negritude, Miami 1987,

Fort de France, édition du Conseil Général de la Martinique (Bureau de la

communication et des relations avec la presse), 2003, pp. 56.

1 À l'occasion du $90^{\mathrm{e}}$ anniversaire d'Aimé Césaire, le Conseil Général de la Martinique a édité le texte du discours qu'il a prononcé lors de la Première conférence hémisphérique des peuples noirs de la diaspora qui a été organisée en son honneur, en 1987, par l'Université Internationale de Floride à Miami. Il s'agit d'une édition bilingue, français/ anglais, présentée par Claude Lise, sénateur de la Martinique et Président du Conseil Général. Le volume est complété par la reproduction d'un extrait du manuscrit de Césaire préparé pour ce discours, par un annexe avec la liste des participants au colloque et les titres de leurs interventions, et surtout par une série de photos de Césaire à la conférence avec d'autres personnalités. Malgré sa brièveté, il s'agit d'un texte important: l'auteur y précise la définition de Négritude, en soulignant essentiellement que ce concept doit dépasser la donnée biologique car il se réfère à une des formes historiques de la condition humaine. Loin d'être une conception philosophique, explique Césaire, la Négritude « est une manière de vivre l'histoire dans l'histoire » (p. 16) et sa valeur identitaire repose moins sur « les chromosomes » que sur «la mémoire collective» (p. 17). Pour Césaire la Négritude semble être identité et recherche de l'identité en même temps, car elle consiste en un engagement et en une résistance continuels visant à conquérir une « nouvelle et plus large fraternité » (p. 27). 